ISSN 0103-5150

Fisioter. Mov., Curitiba, v. 25, n. 3, p. 659-666, jul./set. 2012

Licenciado sob uma Licença Creative Commons

\title{
Feasibility of virtual therapy in rehabilitation of Parkinson's disease patients: pilot study
}

\author{
Viabilidade da terapia virtual na reabilitação de \\ pacientes com doença de Parkinson: estudo-piloto
}

\author{
Ana Paula Cunha Loureiro ${ }^{[a]}$, Cristiane Gonçalves Ribas ${ }^{[b]}$, \\ Talita Gianello Gnoato Zotz ${ }^{[\mathrm{c}]}$, Rebeca Chen ${ }^{[\mathrm{d}]}$, Flávia Ribas ${ }^{[\mathrm{d}]}$ \\ [a] Physical therapist, MS, lecturer at Physical Therapy under graduation, School of Health and Biosciences, Pontifical \\ Catholic University of Paraná (PUCPR), Curitiba, PR, Brazil, e-mail: anna.loureiro@gmail.com \\ [b] Physical therapist, MS, lecturer at Physical Therapy under graduation, School of Health and Biosciences, Pontifical \\ Catholic University of Paraná (PUCPR), Curitiba, PR, Brazil, e-mail: ribas.cristiane@gmail.com \\ [c] Physical therapist, MS, doctoral degree student at Physical Education Program of Federal University of Paraná (UFPR), \\ Curitiba, PR, Brazil, e-mail: talita.gnoato@gmail.com \\ [d] Physical therapists, Curitiba, PR - Brasil, e-mails: rebeca.chen88@gmail.com; flavinhazinha_rs@hotmail.com
}

\begin{abstract}
Introduction: Among Parkinson's disease (PD) motor disabilities, postural and balance alterations are important parameters to physical therapists who need to choose specific, targeted therapies for their patients. Among many therapy options, virtual therapy is studied as to whether it can be a viable rehabilitation method. Objective: To verify the applicability of virtual rehabilitation in PD patients for the improvement of their balance and quality of life. Material and methods: Six volunteers, diagnosed to be in Stages II and III of PD (Hoehn and Yahr Scale), were recruited for this study. Patients (65 \pm 13 years old) participated in activities involving Wii Fit, for a total of twelve interventions, twice per week. Clinical and qualitative methods were used for the data collection for the initial and final evaluations: Borg's Scale, Berg Functional Balance Scale, Time Up and Go, anterior and lateral functional reach and Nottingham's Scale were performed during the study. Penguin Slide, Ski Slalom, Soccer Heading and Table Tilt were the Wii games selected as a form of
\end{abstract}


virtual therapy. Results: The collected data were analyzed using the Wilcoxon test. Motor skill, functional capacities and quality of life were analyzed as variables of the patients' balance. Statistically significant differences were found in the following tests: Borg's Scale $(p=0.0464)$, Berg Functional Balance Scale ( $p$ $=0.0277)$, lateral functional reach to the right $\left(\mathrm{p}=0.0431^{*}\right)$ and lateral functional reach to the left $(\mathrm{p}=$ 0.0277). Conclusion: It is believed that exercises with virtual reality therapy can be a useful tool to improve the balance in PD patients.

Keywords: Parkinson's disease.Virtual reality. Rehabilitation. Balance. Wii Game. Quality of life.

\section{Resumo}

Introdução: Dentre as incapacidades motoras da Doença de Parkinson (DP), as alterações posturais e de equilíbrio são parâmetros importantes para fisioterapeutas que necessitam escolher terapias específicas e direcionadas a seus pacientes. Dentre muitas opções de terapia para essa condição, a terapia virtual é estudada como um método viável para reabilitação. Objetivo: Verificar a aplicabilidade da reabilitação virtual em pacientes com DP para a melhora de seu equilíbrio e da qualidade de vida. Material e métodos: Seis voluntários, diagnosticados como portadores da DP nas fases II e III (escala de Hoehn e Yahr), foram recrutados para este estudo. Os pacientes (de $65 \pm 13$ anos) participaram de atividades envolvendo o Wii Fit, em um total de doze intervenções, duas vezes por semana. Métodos clínicos e qualitativos foram utilizados na coleta de dados para as avaliações iniciais e finais: escala de Borg, escala de equilíbrio funcional de Berg, time Up and Go, reação funcional anterior e lateral e escala de Nottingham foram aplicadas durante o estudo. Penguin Slide, Slalom Ski, Futebol e Inclinação da Mesa foram os jogos de Wii selecionados como forma de terapia virtual. Resultados: Os dados coletados foram analisados utilizando o teste de Wilcoxon. Habilidade motora, capacidade funcional e qualidade de vida foram analisadas como variáveis de equilíbrio dos pacientes. Foram encontradas diferenças estatisticamente significativas nos seguintes testes: escala de Borg ( $p=0.0464)$, escala de equilíbrio funcional de Berg ( $p=0.0277)$, alcance lateral funcional à direita ( $p=0.0431)$ e alcance lateral funcional à esquerda $(p=0.0277)$. Conclusão: Estima-se que os exercícios com terapia de realidade virtual podem ser uma ferramenta útil para melhorar o equilíbrio em pacientes com $D P$.

Palavras-chave: Doença de Parkinson. Realidade virtual. Reabilitação. Equilíbrio. Jogo Wii. Qualidade de vida.

\section{Introduction}

Parkinson's disease is considered a progressive and chronic disease of the nervous system, involving the basal ganglia and resulting in motor damage, consequently disturbing balance and posture (1). As the disease evolves, the head and the trunk remain ventrally flexed, with the superior members in front of the body and the knees bent. Gait disorder includes a slow, short-stepped shuffling and a forward-stooped gait with an asymmetrical arm swing (2). Another important manifestation is a postural reflex, where the reactions of straightening, balancing, and protective extension are decreased by the alteration of sensorial processing (3). Postural responses may also be injured due to the rigidity of the trunk, which doesn't allow an adequate movement of rotation in the longitudinal axis (4).The loss of postural reflexes and also a slow gait velocity have been associated with an increased risk of falls and postural instability, which can have a variety of impacts in the patients' lives, such as morbidity, functional deterioration, hospitalization, institutionalization, and social problems due to the loss of trust in their capacity to undertake daily life activities, leading to social isolation and a greater state of dependence $(5,6)$.

Physical therapy can be an important tool that can help in the treatment of these patients. The therapeutic program can be administered individually or in a group, and its duration and frequency will depend on the phase and dysfunction found in the patient. The therapeutic exercises can maintain physical conditioning, preserve muscular activity and flexibility, and improve balance. They have also been found to decrease depression and lack of 
initiative which often occur in Parkinson's disease (7). Various resources and tactics can be used, such as fit balls $(8)$, resistance exercises $(9,10)$, treadmill with partial weight support $(11,12)$, aerobic exercises (13), acupuncture (14), and hidrotherapy $(15,16)$. In recent years, virtual reality technologies have been studied as tools for the evaluation and treatment in neurorehabilitation $(17,18)$.

Virtual reality works in a multisensory and multidimensional environment. The main objectives in rehabilitation by virtual reality through different software, exercises and rehabilitation techniques, would be the increase of functional ability and the raise in the participation of the patient in daily life, which can be reached through the improvement of sensory, motor, and cognitive functions, in a way that can stimulate and motivate the individual to his or her own recovery (19).

One of the new resources available for virtual reality is Nintendo's Wii videogame and its derived products, such as Wii Fit. Its interactive games can help in the recovery of motor skills, working on one's coordination skills, strength, and reasoning, which enable it to interact lucidly and rehabilitate at the same time (20).

This research had the objective of verifying the applicability of virtual rehabilitation in PD patients for the improvement of their balance and quality of life.

\section{Material and methods}

\section{Participants}

We conducted the study with six patients of both sexes ( $65 \pm 13$ years old), belonging to the Parkinson Association of Curitiba. All patients were at intermediate level (Hoen \& Yahr Stage II-III) (21), with a difficulty in walking (defined by Unified Parkinson's Disease Rating Scale - UPDRS, motor part), but able to walk without assistance for at least five minutes. To be included in the study, patients had to be in PD stages II or III, according to the Hoen and Yahr Scale while in the OFF-medication phase (in absence of the effect of medication) and lack of dementia (MiniMental State Examination score $\geq 24$ ). The exclusion criteria were the following: existence of a serious chronic disease (orthopedic, neurological or psychiatric); severe visual impairment; unable to walk independently; had undergone treatment for PD.
As part of the selection procedures, the volunteers were asked to sign the informed consent to participate in the experimental procedure, as required by the Declaration of Helsinki and the Institutional Research Ethics Committee of PUCPR, approved under number $0002940 / 09$. These patients were not involved in any other form of physical activity throughout the duration of the study.

\section{Assessments}

The following evaluations were performed at the beginning and at the end of interventions under the same conditions throughout the whole program, and their brief descriptions are the following:

a) Borg's Scale: To establish relationships between perceived exertion and objective data of external load, or physiological stress.

b) Berg Functional Balance Scale (BFS): To determine risk factors for loss of independence and falls in the elderly. Evaluates the performance of functional balance of fourteen common items in daily life.

c) Notthingham's Scale: To assess quality of life.

d) Time Up and Go (TUG): Quick monitoring to detect balance problems that affect activities of daily living in elderly.

e) Functional Reach: Developed as a quick monitoring of balance problems in the elderly. The test determines how well the individual is able to move with stability.

\section{Intervention programs}

The treatment plan consisted of two visits per week lasting 20 minutes each, over a period of five weeks of interventions during $\mathrm{ON}$-periods (in presence of the effect of medication). The patients' blood pressure was measured before and after the intervention with the purpose of monitoring the vascular response to the exercises in order to prevent a cardiovascular overload.

The dynamic therapy with the Wii Fit exercises consisted of three planes of motion (sagittal, frontal and transversal) at lower difficulty levels of the game, targeting stretching exercises and balance training using the balance board. Among various 
types of games, the following six were selected for the study:

\section{- Stretching Exercises:}

- Half Moon: the patient performs the inclination of the trunk stretching the muscles of the lateral regions of the upper, lower limbs, and the trunk. This is repeated on the opposite side.

- Balance Training Exercises:

- Penguin Slide: the patient simulates a catching of the fish jumping in the water for points. The game consists of latero-lateral displacements. - Ski Slalom: the patient tries to zig-zag between red and blue flags without missing any flag. The more the patient leans the trunk forward, the faster he is able to weave through the flags.

- Soccer Heading: just like heading of the ball in soccer, the patient has to head the ball which comes toward him and deflect the ball away from the heads of pandas. If the ball lands on the pandas, it results in reduction of points.

- Tightrope Walk: the patient must traverse a tightrope without falling off or without disturbing various barriers along the way.

- Table Tilt: the patient is presented with a table with various holes in it. Then, he must try to direct the balls into the holes by tilting the table.

Throughout all the balance training exercises, strengthening exercises were performed in parallel.

\section{Statistical analysis}

We assessed the relationship between motor learning, functional capacity and the balance of patients by looking at the following: Borg' Scale, Berg Functional Balance Scale, Time Up and Go, Anterior Functional Reach, Right and Left Functional Reach and Quality of Life for Nottigham Scale. For this purpose, we performed the Wilcoxon test, values were considered significant when $\mathrm{p} \leq 0.05$.

\section{Results}

The Borg Scale (Figure 1A) results show a significant relevance between the baseline and the final groups $(\mathrm{p}=0.0464)$.
The Berg Functional Balance Scale results were statistically significant when comparing the initial and the final assessments (Figure 1B).

The Time Up and Go test was not statistically significant when comparing the initial and final values (Figure 1C).

The following values show the evaluation of the functional range: anterior, lateral right and left side (Figure 2).

The assessment of quality of life by the Nottingham Scale showed no statistical significance between the initial and the final evaluations (Figure 3).

\section{Discussion}

The virtualization technology is an emerging reality with a variety of benefits for the recovery aspects of the assessment, treatment and research (22). Research and understanding of this technology will be crucial for effective integration into rehabilitation. This requires a period of adaptation of new technological resources, especially in individuals who do not have the practice of virtual technology $(23,24)$.

Virtual reality systems are new and potentially useful technologies that allow users to interact in three dimensions with a computer generated scenario. It is known that the conventional treatment of neurological patients is based on repetition of movements for the acquisition or retrieval of motor patterns. Therapy with virtual technology can also work with the repetition of movements and allows the user to interact with the system and receive feedback on their performance in real time (24). It therefore incorporates the principles of motor learning and at the same time offers engaging and challenging training in complex environments (25).

Although the use of virtual rehabilitation activities have grown in recent years, little research has been reported in the therapeutic management of people with Parkinson's disease. This pilot study used interactive games in the hopes of stimulating specific movements and benefits related to balance control and quality of life. People affected by Parkinson's disease have a higher propensity for falls and postural instability. In a study by Scandale et al. (9), they used two groups of 32 individuals, a group affected by PD and another group of healthy people. It was found that the PD group had a slower 


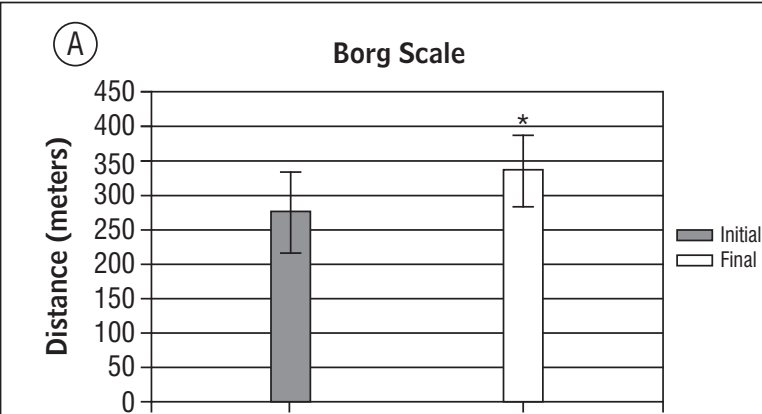

(B) Borg Functional Balance Scale

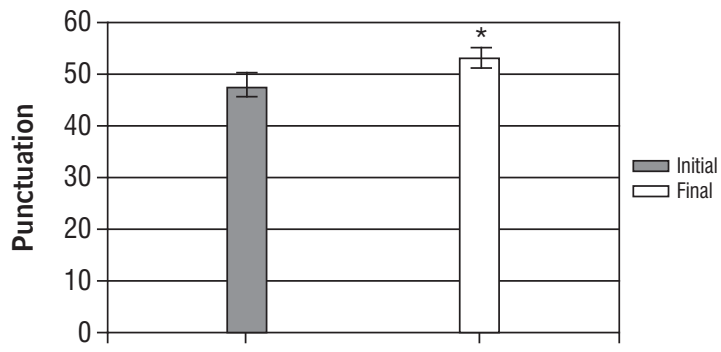

(C) Time Up and Go

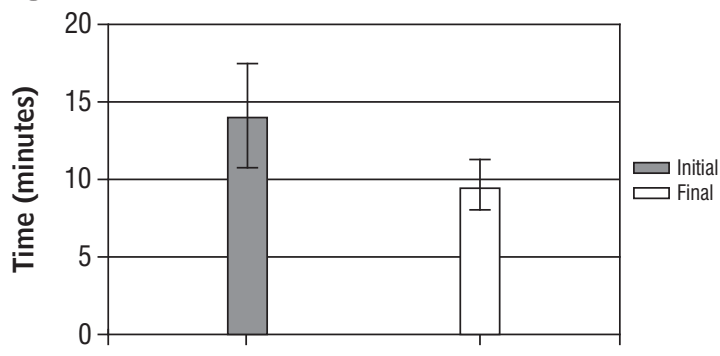

Figure 1 - Borg Scale, Berg Functional Balance Scale and Time Up and GO

A) The results of the Borg scale are expressed as mean \pm standard deviation. * Statistically significant when compared to the Borg Scale Initial and Final (Wilcoxon). B) The results for the Berg Functional Balance Scale are expressed as mean \pm standard deviation. * Statistically significant when compared to the Borg Scale Initial and Final (Wilcoxon). C) The results are expressed as mean \pm standard deviation, related to initial assessment and final Test Time Up and GO.

Source: Research data.

gait, stride length and cadence in a 6-minute walk test. Furthermore, Shenkman et al., in their 2001 (10) study, found a deficit in functional mobility in PD patients while performing the 6-minute walk test, which is a test for functional capacity in PD patients.

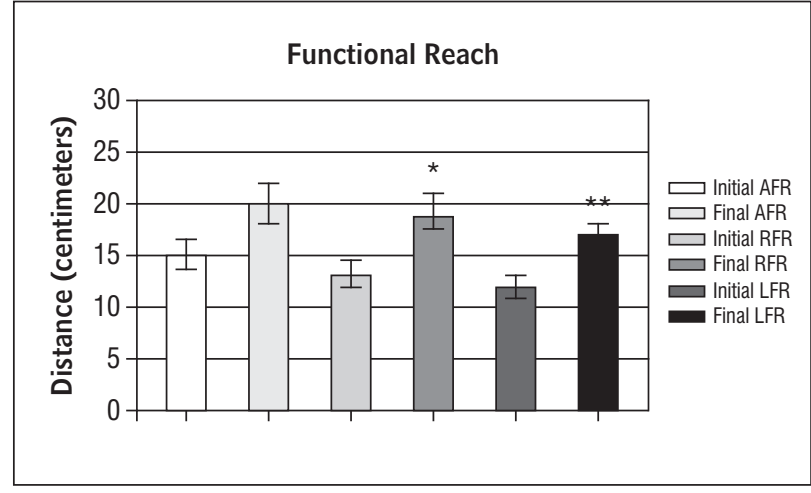

Figure 2 - Functional Reach

Source: Research data.

Legend: AFR - anterior functional reach; RFR - right functional reach; LFR - left functional reach.

Note: Results are expressed as mean \pm standard deviation.

* Significant ( $p=0.0431)$ when compared to the initial and final evaluation (Wilcoxon).

** Significant $(p=0.0277)$ when compared to the initial and final evaluations (Wilcoxon).

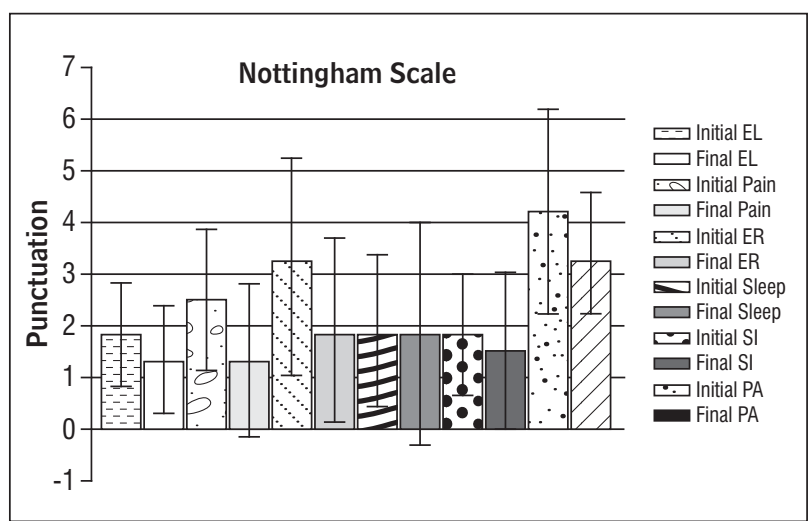

Figure 3 - Nottingham Scale

Source: Research data.

Legend: $E L=$ energy level; $E R=$ emotional reactions; $\mathrm{SI}=$ social interaction; $\mathrm{PA}=$ physical abilities.

Note: Results expressed as mean \pm standard deviation.

At the end of intervention with Wii Fit, there were no significant differences in relation to the Time Up an Go test, however it was found that participants traveled more distance in the same interval of time in the initial assessment, as measured by the Borg Scale (Figure 1). This result was significant. The gains made by the participants show a drop in stress levels and fatigue to perform these daily activities. 
Rehabilitation with Wii Fit features favorable results with respect to fatigue, suggesting that it takes less effort to perform daily activities (24-26). The use of this technology for treatment of cerebral palsy was efficient in terms of improved fitness for walking (26). The effects of virtual reality on the level of effort for everyday tasks, is also reported in patients with cerebrovascular accident (CVA), and despite the reduction of fatigue in these patients, no significant results were indicated in a study that compared the stress levels of patients in Group Wii Fit with Recreation Therapy Group (24).

It can be observed that the participants in this study had a statistically significant increase in points in the initial evaluation and final Berg Functional Balance Scale. It is believed that this may be related to the balance exercises with Wii Fit. The improvements observed in our study are in line with the Schiaviato study (27). Recent work with hemiparetic stroke complications by performing physical therapy with Wii Fit showed greater control of static and dynamic balance in accordance with the Berg Balance Scale, and reduced mediolateral sway in the stabilometry test (22). By using Wii Fit in a patient with cerebellar dysfunction to determine the influence of virtual reality on the balance, it was found that the patient had an increase of $23.21 \%$ in the BFS, as well as greater independence to perform daily tasks (27).

The participants in this study showed significant improvements in functional right and left lateral movements (Figure 2) despite some signs of muscular stiffness, impaired postural reactions, decreased range of motion for straightening of the trunk, reduced balance and protective extension.

A study of elderly patients undergoing balance training using Wii Fit showed improved balance, which was verified by analysis of center of pressure (28).

In addition to these clinical parameters, we must consider the social, mental and emotional factors that reflect the quality of life (29-31). It is critical that the treatment of PD try to promote social interaction and improve the quality of life of these patients. Although the Wii Fit therapy has brought improved results as reported by the participants of this study, they were not sufficient for statistical significance for conclusive evidence in evaluating the quality of life. Despite the growing number of studies using Wii Fit balance training, very few in the literature target the patients these studies examined. Therefore, there needs to be further research in this endeavor.

\section{Conclusion}

The Virtual Reality therapy using Wii Fit showed statistically significant improvements in the patients' balance and provides the basis for future research in larger trials. It is believed that exercises with virtual reality therapy can be a useful tool for the following reasons: stimulation of voluntary muscles; sensitization of initial system through constant oscillations of the body on the platform and during the basic movements; activation of somatosensory system by various positions of body segments during different amplitudes of movements; and engaging set of tasks and real-time feedback. All this leads to the potentialization of the system of balance adjustments. Moreover, the playful, dynamic and fun aspects of the virtual therapy may also contribute to improved motivation and willingness for therapy and at the same time may lead to reduction of apathy among patients.

This pilot study suggests that the virtual reality represents a potentially effective alternative to facilitate physical therapy that should emphasize the relationship between balance control improvements and external sensory stimuli.

The authors declare no conflict of interest in financial, personnel, political party, religious or other nature that may interfere with their freedom of dissemination of the study.

\section{References}

1. Bloem BR, Van Vugt JP, Beckley DJ. Postural instability and falls in Parkinson's disease. Adv Neurol. 2001;87:209-23. PMid:11347224.

2. Morris ME, Martin CL, Schenkman ML. Striding out with Parkinson disease: evidence-based physical therapy for gait disorders. Phys Ther. 2010;90(2):280-8. doi:10.2522/ptj.20090091.

3. Boonstra TA, Van Der Kooij H, Munneke M, Bloem BR. Gait disorders and balance disturbances in Parkinson's disease: clinical update and pathophysiology. Curr Opin Neurol. 2008;21(4):461-71. doi:10.1097/ WC0.0b013e328305bdaf. 
4. Bartolić A, Pirtosek Z, Rozman J, Ribaric S. Postural stability of Parkinson's disease patients is improved by decreasing rigidity. Eur J Neurol. 2005;12(2):156-9. doi:10.1111/j.1468-1331.2004.00942.x.

5. Aragão FA, Navarro FM. Influências do envelhecimento, do tempo de evolução da doença e do estado cognitivo sobre os episódios de quedas, em uma população parkinsoniana. Fisioter Bras. 2005;6(4):250-4.

6. Dennison AC, Noorigian JV, Robinson KM, Fisman DN, Cianci HJ, Moberg P, et al. Falling in Parkinson disease: identifying and prioritizing risk factors in recurrent fallers. Am J Phys Med Rehabil. 2007;86(8):621-32. doi:10.1097/PHM.0b013e311611583.

7. Silberman CD, Lacks J, Rodrigues CS, Engelhardt E. Uma revisão sobre depressão como fator de risco na Doença de Parkinson e seu impacto na cognição. Rev Psiquiatr. 2004;26(1):52-60.

8. Haase DCBV, Machado DC, Oliveira JGD. Atuação da fisioterapia no paciente com doença de Parkinson. Fisioter Mov. 2008;21(1):79-85.

9. Scandalis TA, BosakA, Berliner JC, Helman LL, Wells MR. Resistance training and gait in patients with Parkinson's disease. Am J Phys Med Rehabil. 2001;80(1):3843. doi:10.1097/00002060-200101000-00011.

10. Schenkman ML, Hall D, Kumar R, Kohrt WM. Endurance exercise training to improve economy of movement of people with Parkinson disease: three case reports. Phys Ther. 2008;88(1):63-76. doi:10.2522/ ptj.20060351.

11. Miyai I, Fujimoto Y, Ueda Y, Yamamoto H, Nozaki S, Saito T, et al. Treadmill trainingwith body weight support: its effect on Parkinson's disease. Arch Phys Med Rehabil. 2000;81(7):849-52. doi:10.1053/apmr.2000.4439.

12. Frazzitta G, Maestri R, Uccellini D, Bertotti G, Abelli P. Rehabilitation treatment of gait in patients with Parkinson's disease with freezing: a comparison between two physical therapy protocols using visual and auditory cues with or without treadmill training. Mov Disord. 2009;24(8):1139-43. doi:10.1002/ mds.22491.

13. Bergen JL, Toole T, Elliott RG, Wallace B, Robinson $\mathrm{K}$, Maitland CG. Aerobic exercise intervention improves aerobic capacity and movement initiation in Parkinson's disease patients. NeuroRehabilitation. 2002;17(2):1621-28.
14. Marucci FCI, Cardoso NS, Berteli KS, Garanhani MR, Cardoso JR. Alterações eletromiográficas dos músculos do tronco de pacientes com hemiparesia após acidente vascular encefálico. Arq Neuropsiquiatr. 2007;65(3-b):900-5. PMid:17952306.

15. Finger $A V$, Prado ALC, Boff SM. A fisioterapia aquática atuando na melhora das atividades de vida diária em pessoas com doença de Parkinson. Revista da Saúde. 2003;7(1):109-17.

16. Loureiro APC, Gnoato TG, Viana J, Israel VL. Improvement of aquatic motor schemes aimed at further increasing of balance in patients affected by Parkinson's disease in the intermediate stage. 2010;1:163-76.

17. Sveistrup H. Motor rehabilitation using virtual reality. J Neuroeng Rehabil. 2010;1:1-10.

18. Broeren J, Claesson L, Goude D, Rydmark M, Sunnerhagen KS. Virtual rehabilitation in an activity centre for community-dwelling persons with stroke. Cerebrovasc Dis. 2008;26(3):289-96. doi:10.1159/000149576.

19. Weiss PL, Rand D, Katz N, Kizony R. Vídeo capture virtual reality as flexible and effective rehabilitation tool. J Neuroeng. Rehabil. 2004;1(1):12. doi:10.1186/1743-0003-1-12.

20. Torres A, Zagalo N. Videojogos: um novo meio de entretenimento de idosos? In: Atas do 5 SOPCOM Comunicação e Cidadania. Braga: Universidade do Minho; 2007.

21. Hoehn MM, Yahr MD. Parkinsonism: onset, progression and mortality. Neurology. 1967;17(5):427-42. doi:10.1212/WNL.17.5.427.

22. Barcala L, Colella F, Araujo MC, Salgado ASI, Oliveira CS. Análise do equilíbrio em pacientes hemiparéticos após o treino com o programa Wii Fit. Fisioter Mov. 2011;24(2):337-43. doi:10.1590/ S0103-51502011000200015.

23. 23. Srivastava A, Taly AB, Gupta A, Kumar S, Murali T. Poststroke balance training: role of force platform with visual feedback technique. J Neurol Sci. 2009;287(1-2):89-93. doi:10.1016/j.jns.2009.08.051.

24. Saposnik G, Mamdani M, Bayley M, Thorpe KE, Hall J, Cohen LG, et al. Effectiveness of virtual reality exercises in stroke rehabilitation (EVREST): rationale, design, and protocol of a pilot randomized clinical trial assessing the Wii gaming system. Int J Stroke. 2010;5(1):4751. doi:10.1111/j.1747-4949.2009.00404.x. 
25. Mirelman A, Maidan I, Herman T, Deutsch JE, Giladi $\mathrm{N}$, Hausdorff JM. Virtual reality for gait training: can it induce motor learning to enhance complex walking and reduce fall risk in patients with Parkinson's disease? J Gerontol A Biol Sci Med Sci. 2011;66(2):23440. doi:10.1093/gerona/glq201.

26. Deutsch JE, Borbely M, Filler J, Huhn K, Guarrera-Bowlby P. Use of a low-cost, commercially avaiable gaming console (Wii) for rehabilitation on an adolescent with cerebral palsy. Phys Ther. 2008;88(10):1196-207. doi:10.2522/ptj.20080062.

27. Schiavinato AM, Baldan C, Melatto L, Lima LS. Influência do Wii Fit no equilíbrio de paciente com disfunção cerebelar: estudo de caso. J Health Sci Inst. 2010;28(1):50-2.

28. Rojas VG, Cancino EE, Silva CV, López MC, Arcos JF. Impacto del entrenamiento del balance a través de realidad virtual em uma población de adultos mayores. Int J Morphol. 2010;28(1):303-8.
29. Goulart F, Teixeira-Salmela LF, Barbosa CM, Silva CM. Impact of physical activity program on quality of life in parkinson's disease patients. Anais do Congresso Brasileiro de Psicologia do Esporte. Rio de Janeiro: Associação Brasileira de Psicologia do Esporte; 2003.

30. Kuopio AM, Marttila RJ, Helenius H, Toivonen M, Rinne UK. The quality of life in Parkinson's disease. Mov Disord. 2000;15(2):216-23. doi:10.1002/15318257(200003)15:2<216::AID-MDS1003>3.0.CO;2-\#.

31. Camargos ACR, Copio FCQ, Sousa TRR, Goulart F. Impact of parkinson's disease on quality of life: literature review. Rev Bras Fisioter. 2004;8(3):267-72.

Received: 07/26/2011

Recebido: 26/07/2011

Approved: 02/08/2012

Aprovado: 08/02/2012 